\title{
Effects of corona-virus outbreak on micro and small scale enterprise operation in southwest Ethiopia
}

\author{
Bayelign Abebe Zelalem¹, Ayalew Ali Abebe ${ }^{1}$ \\ ${ }^{1}$ College of Business and Economics, Mizan-Tepi University, Ethiopia.
}

How to cite: Zelalem, B.A. and Abebe, A.A. (2021), "Effects of corona-virus outbreak on micro and small scale enterprise operation in southwest Ethiopia", Brazilian Journal of Operations \& Production Management, Vol. 18, No. 02, e20211167. https://doi.org/10.14488/BJOPM.2021.035

\section{ABSTRACT}

Goal: This examination is expected to survey the effect of COVID-19 for micro and small scale enterprise activity in southwest Ethiopia.

Design / Methodology / Approach: The current study used the graphic exploration plan which includes 346 micro and small-scale enterprises. Enterprise proprietors, government authorities, and specialists were invited to answer self-administered questionnaires and information was also acquired from archive audit of different reports and exploration results zeroing.

Results: The analysis revels that the outbreak of the pandemic had a negative impact on production, employment, profit, seals level, operation costs and cost of raw material by $59 \%, 35 \%, 78 \%, 72 \%, 49 \%$, $10 \%, 10 \%, 31 \%$ and $59 \%$ respectively. The virus also has a $10 \% 9 \%$ and $8 \%$ impact on local government tax revenue collected from the urban, services, and construction sectors, respectively. The virus has no impact on the manufacturing industry but has a positive effect on the trading sector; finally, the outbreak had a significant impact on the enterprises supply chain with a rate of $48 \%$.

Limitations of the investigation: The examination have the accompanying constraints first; the consequences of this investigation are not summed up to different segments other than Micro and small scale enterprise. Second the investigation utilized qualitative data that can't fill the advantage of quantitative data. Thus, there must be further examination on the effect of COVID 19 in various benefit arranged and non- benefit arranged associations and even in the micro and small scale enterprise by joining other comports of operation that have not been contacted in the investigation.

Practical implications: The result of this study has some important implications for micro and small scale enterprise owners and the government. In this way, the examination gives insight to micro and small scale enterprise to take activities like moving their activity to related business and creation of right now requested defensive materials. Moreover, the investigation gives insight to the government and different partners on how COVID 19 affects both the micro and small scale enterprise as well the public tax.

Originality / Value: This study is the first of its kind up to authors' knowledge, and the data was collected from the most authentic sources.

Keywords: COVID-19; micro and small scale enterprise; government tax revenue and employment; production level and seals level.

\section{INTRODUCTION}

Covid-19 broke out in Wuhan, China. Notwithstanding, as of October 10, COVID-19 is now present in 214 nations around the globe, 36,886,080 individuals are tainted, 1,068,225 individuals have kicked the bucket, and 25,664,292 individuals have recuperated. Since the

Financial support: None.

Conflict of interest: The authors have no conflict of interest to declare.

Corresponding author: rafamtu@gmail.com

Received: 18 February 2021.

Approved: 03 May 2021.

Editor: Syed Abdul Rehman Khan. 
start of time in Africa, the primary the situation was accounted for Egypt is a country where infection has grown to 53 nations inside a week. In Ethiopia, absolute of 44,099 cases and 1,262 passing's were accounted for by on the Ministry of Health October 8, the year 2020 (Ethiopia, 2020).

'The' flare-up in the pandemic of COVID-19 has begun upset the political situation, monetary, social in addition to strict and money related the world's structure. To place this is the financial viewpoint, along with supported according to Duffin (2020), worldwide monetary development had just been estimated for diminish a decrease of 3\% to 2.4 percent. 'Consequently' author ascribed it is monetary harm and limitation based movement as well as the drops sought after. The pandemic has begun likewise to be required influence a lot more African nations. Dreadlocks financial development, according to expectation by the African Economic Commission (Economic Commission for Africa, 2020), diminishes from 1.8 percent in the previous year to 1.8 percent in the current year most ideal situation as well as withdrawal if the rate is 2.6 percent, most pessimistic scenario occur.

With the Ethiopian government's expansion in terms of quantity individuals contaminated COVID-19 is the latest version of COVID legislature proclaimed highly sensitive situation meaning to check the disease's propagation infection as in country. 'For this' highly sensitive situation brings limitation of the movement in particular human versatility that also exacerbated antagonistic impact in the this same economy, as well as organizations especially miniature in turn little areas. This impact too much is expected exploration centered on proof this illustrates the degree on which micro and small scale enterprises are influenced. In spite of the fact that there are reports coming out of various news sources, likewise assessment seems to be needed through uncover the consequence of it's uncommon this same virus outbreak for it's indeed micro in addition small scale and give the potential arrangements. Thus far, there has been none investigation seems to be directed here on issue. Presently, the span of years has come with react the referenced gap through quick appraisal of COVID 19's repercussions for little and on a on a tiny level enterprise activity and give knowledge to leaders in the area and for specialists to direct further examination. Therefore, the study estimates the effect of corona virus on the micro and small scale enterprise operation and assess the effect of corona virus on the government tax revenue collected from micro and small scale enterprise in south west Ethiopia.

\section{LITERATURE REVIEW}

The COVID-19 global epidemic, also known as COVID, is a global test that necessitates collaborative efforts from governments, individuals, organisations, and other stakeholders. The global economy is experiencing notable and extraordinary shocks as the pandemic causes a variety of shocks, including health, flexibility, demand, and financial shocks (Triggs and Kharas, 2020). Government's attempts to monitor the COVID-19 pandemic by fractional and complete business closures unavoidably result in a general decline in monetary activities locally and globally. If the pandemic continues for an extended period of time, this restriction of monetary activities leads to a financial downturn. As per studies, social orders with a lower economic position are more vulnerable against the COVID-19's relentless infectious disease, that is further exacerbated by monetary and social government assistance challenges (International Labour Office, 2015). As a result, performance is further eroded and medical care rates go up, leading to increased destitution and, as just a consequence, further infection. This is a "impoverishment pit caused by sickness." From a monetary standpoint, the most important factor is also not the number of COVID-19 cases, but the degree of disruption to business dealings, which exasperates the level of medical risks.

As shown in a report by the Planning and Development Commission (2018), the destitution versatility of growth was $-2 \%$, meaning that a $1 \%$ change in development rate leads in a 2\% decrease in neediness around 1996 and 2016 (Planning and Development Commission, 2018). Individually, the percentages for country and urban centers were -2.1 and -1.5 percent. The pandemic will reduce Ethiopia's financial growth by $3 \%$ in 2020 , according to 
preliminary evidence (World Bank, 2020). Our findings indicate that the pandemic will reduce Ethiopia's profit development by 2.2 percent to 9.9 percent in 2020, depending on the number of loss of jobs and the length of the pandemic.

Ozili and Arun (2020) explored the role of COVID19 on the globalized trade. The findings show that the growing number of lockdown days, money-related strategy options, and international travel restrictions have a major impact on the degree of monetary movement and the end opening, most minimized, and most prominent stock cost of significant market financial exchange history. Surprisingly, the forced restraint on inner development and greater monetary approach spending had a positive effect on the fairness and squareness of financial exercises, despite the fact that the growing complete amount Covid cases had no substantial impact on the degree of business methodology. Further to that, the influence of COVIDE 19 on the Indian economy (by 2020) has been assessed, and the findings show that COVID 19 has a stamped effect on 53 percent of Indian firms, as well as 60 percent of dynamic supply chain operations and 80 percent of revenue.

WFP-Regional Bureau VAM/M\&E/Nutrition/Supply Chain 2020 undertook a financial and market impact analysis of COVID-19 on West and Central Africa. From 0.86 percent in 2008 to 3.7 percent in 2019, the CPI for generally increases by 3.7 percent. Since yields are likely to be higher only with start of the lean season, additional increases as a result of Covid-19, as well as gracefully limitations or interruptions, may exacerbate food insecurity, especially in importdependent countries. Another unnoticed effect would be the decline in settlements from developed countries, as transients from West African countries, who are usually illegal outsiders in Europe, are still unable to work and thus will not be able to send money home at this period. Covid-19 seems to have an important consequence on social job capability in every economy. Persons who become ill with Covid-19 are just unable to function, and those who are not yet ill may be restricted from doing so due to prevention and amelioration strategies. The lost employment prospects in low-pay economies can have an influence on the business and jobs, since the plurality of positions are in the casual sector and farming, while many positions in the traditional sector are with organizations that need liquidity to stay in business and pay their bills throughout that downturn. Around $26 \%$ of the community was affected by the cliché environment.

In the mild and severe scenarios, the effect of the COVID-19 on total and sectorial value added (or GDP) is seen. For two instances, the percentage reduction in GDP due to the pandemic is calculated for two pandemic durations (three and six months) (mild and severe). The fall in gross and sector - specific GDP due to layoffs is measured against baseline GDP (i.e. in the absence of the pandemic). It's also worth noting that the percentage decrease in GDP for each pandemic period corresponds to the contraction in Gross domestic product throughout those cycles. The economy will lose approximately ETB 44.5 billion, or 2.2 percent of Gross domestic product, under the mild scenario with a three-month period, relative to the baseline, with the service sector experiencing a large contraction (3.8 percent). The rural population, as predicted, is the negatively liked. Even so, if the pandemic lasts too long and is mild, the economy suffers a substantial loss of ETB 139.2 billion, or 6.7 percent of GDP, compared to the base case. If the pandemic lasts six months, the services and manufacturing industries will be hard hit, meaning that the severity of the economic burden rises as the pandemic progresses (Goshu et al., 2020).

In the extreme scenario, if the outbreak lasts three months, about 3.6 percent of total GDP from productivity growth would be missed. This corresponds to a deficit of more than 74 billion birr in just three months. In this case, the COVID-19 has a very high influence on service sector in terms of reducing GDP (reduction of about 6.1 percent of annual GDP within three months), followed by construction and manufacturing (reduction of about 3\%), and cultivation (reduction of around 1\%). (Goshu et al., 2020). That being said, if the pandemic lasts six months, the optimistic case will mean a loss of 9.9\% of total GDP. That means the state will lose over 204 billion Birr over the next six months. COVID-19 has a large effect on the service sector in terms of GDP decline (significant decrease of 15.7 percent in 6 months), followed by manufacturing and construction (reduction of about 9.9 percent), and agriculture (reduction of about 2.4 percent). deRitis et al. (2020). 


\section{RESEARCH METHOD}

\subsection{The study Area}

This study was conducted on three Zones which are found under Southern, Nations, Nationalities, and People's Regional (SNNPR) in the southwestern part of Ethiopia namely, Bench-Sheko, West-Omo, and Sheka Zones. Mizan Aman is the capital town of Bench Sheko Zone, which is arranged $561 \mathrm{Km}$ far away from Addis Ababa, the capital city of the nation. The complete populace of Mizan-Aman town is 50,113, of which 24,956 are guys and 25,157 are females. West-Omo Zone is the newly formed zone which formerly incorporated with Bench Maji and Jemu is the capital town of the Zone. Sheka is the third Zone in this study and this Zone is bordered on the south by Bench Maji, on the west by the Gambela Region, on the north by the Oromia Region, and on the east by Keffa.

\subsection{Research design}

This investigation utilized graphic exploration plan so as to survey the COVID-19 has an influence for very little and just that little scale in the business south west Ethiopia. As indicated by Kothari (2004), in engaging examination, the analysts can just asses what has occurred or what's going on. The examination has embraced subjective exploration approach. As per Hoepfl (1997), subjective exploration strategy can be utilized to increase new points of view on issues not many or little is as of now known, or to acquire data that might be hard to pass on quantitatively. A tale Corona infection carries another test to organizations and its genuine effect is yet to be found. This examination gave very noteworthy subjective data on the effect of pandemic for micro and small scale enterprise.

\subsection{Research approach, sources of data and collection method}

The approach of dealing with the community is alluded to as the research strategy. There are three main types of research methodologies. There are three types of tests performed: qualitative, empirical, and combined. A qualitative analytical method was used in this analysis. The analysis drew on both secondary sources of information of data. From November 5 to November 25 2020, two researchers approached company executives and invited them to completed self-administered survey questions. The survey was immediately transferred, and written consent was received from the owners of microenterprises, public officials, and experts. Prior to data collection, the study's aims, the confidentiality of individual information, and other safety standards stated in the survey guidelines were explained to the participants. They were given the task of addressing as many queries as they can and. Secondary information was acquired from archive audit of different reports and exploration results zeroing in for the micro and small scale enterprise. As explained below in table 1 from the complete of 2,164 micro and small scale enterprise 346 were picked utilizing separated examining strategies.

Table 1: Sample selection of micro and small-scale enterprise

\begin{tabular}{lllllll} 
Zones & Manufacturing & Urban Agriculture & Trade & Service & Construction & Total \\
B/Sheko & 47 & 63 & 63 & 44 & 35 & 252 \\
West Omo & 4 & 13 & 8 & 9 & 4 & 38 \\
Sheka & 10 & 13 & 8 & 12 & 13 & 56 \\
Total & 61 & 89 & 79 & 65 & 52 & 346 \\
\hline
\end{tabular}

Source: Researchers own computation (2020)

The information's gathered through examiner were broke down utilizing table, number, and rate Hence, this investigation planned to survey the overall circumstance of micro and small scale enterprise and what happed With the spread of the COVID-19 contagion in south 
west Ethiopia. 'Consequently' information gathered through examiner and report examination were incorporated together so as to produce the after effects of the investigation.

\section{RESULTS AND DISCUSSION}

\subsection{Classification of respondents by sector}

Figure 1 below shows that $26 \%$ of the respondents were occupied with urban agriculture followed by trade (23\%), services (19\%), construction (15\%) manufacturing $(17 \%)$ respectively.

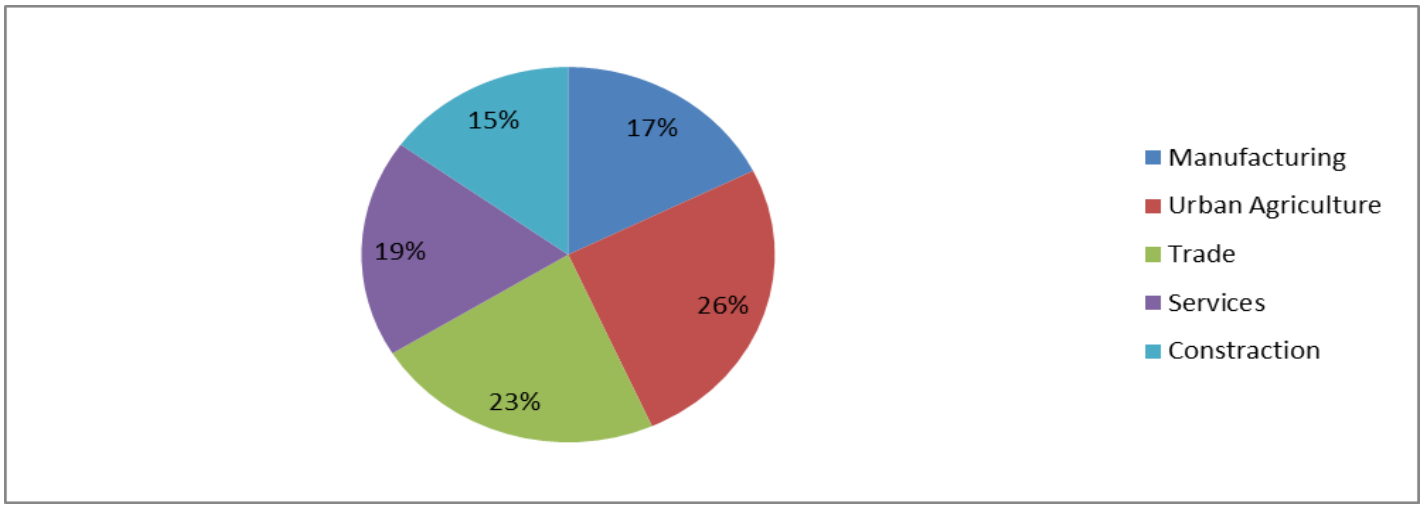

Figure 1: Micro and small scale enterprise business types

\subsection{Status of enterprise by ownership structure}

Interms of possession structure of respondents figure 2 below shows that $65 \%$ of micro and small scale enterprise are self-recognized as sole ownership and $35 \%$ are association

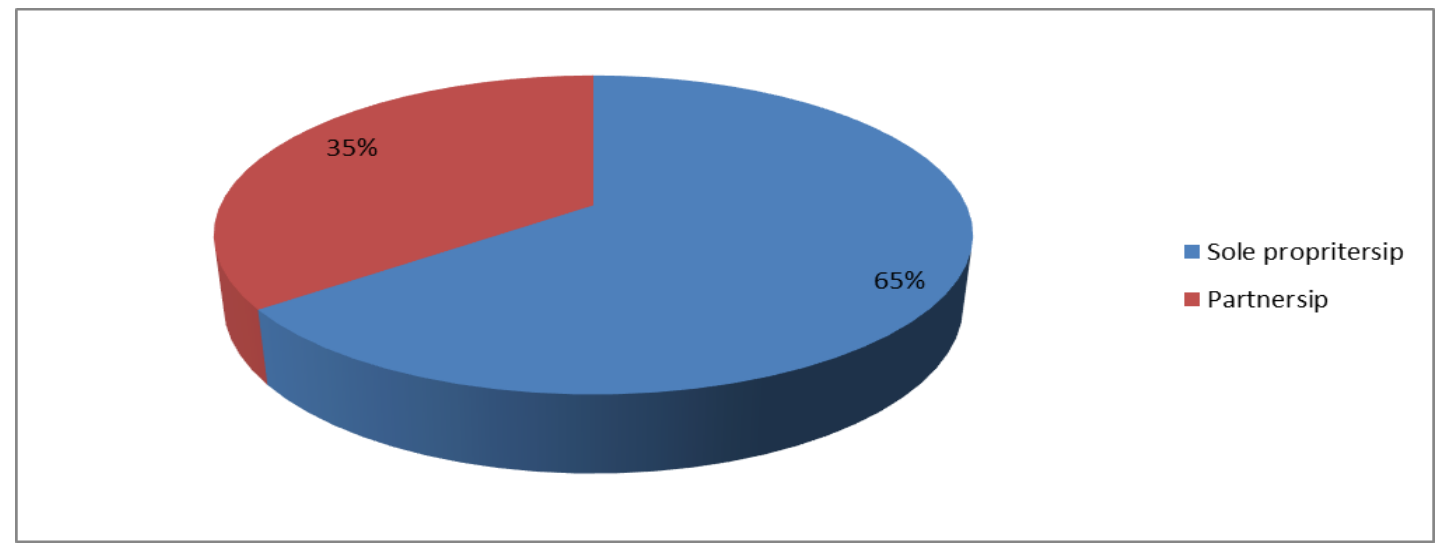

Figure 2: ownership structures of micro and small scale enterprises

\subsection{Effect of COVID 19 on micro and small scale enterprise production}

Figure 3 below shows that $59 \%$ of micro and small scale enterprises confess to have encountered a decrease production/work exercises/because of COVID 19 outbreak, 19\% of micro and small scale enterprises confess to have encountered production level unaltered, $10 \%$ of micro and small scale enterprises confess to have encountered expanded yield and $12 \%$ of the enterprise halted production. The finding of this paper is consistent with the report of international organization for migration (2020) which states that covid 19 has negatively impacted SMEs production level with an average decline of $67 \%$ across all sectors in Iraq. Similarly, the result of this study is consistent with Kumar et al. (2020) who founded that the outbreak affected the sustainable production and operation management. 


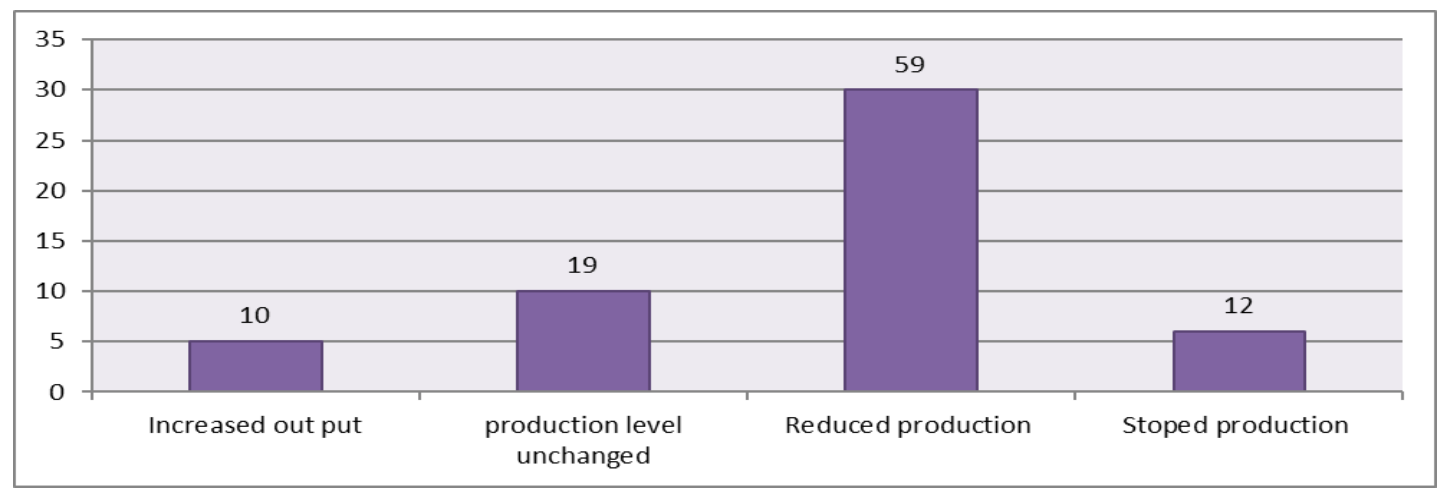

Figure 3: Micro and small scale enterprise production levels

\subsection{Effect of COVID 19 on Employment}

Respondents were gotten some information about any adjustment in the quantity of workers drew in during COVID 19 outbreak contrasted with the earlier year. Most of the respondents revealed that they had kept up similar number of employment at 55\% expanded and diminished at 10\% and 35\% separately because of the out brake. This study's results are consistent with those of Wilkinson (2020), which claims that due to Covid 19, 11.1 percent of working hours were lost in low-income countries in 2020 as opposed to 2019. The results of the study back up the observations of the International Organization for Migration 2020 research, which claims that the pandemic has had a significant effect on businesses' ability to retain employees. There have been 27 percent declines in full-time workers on average.

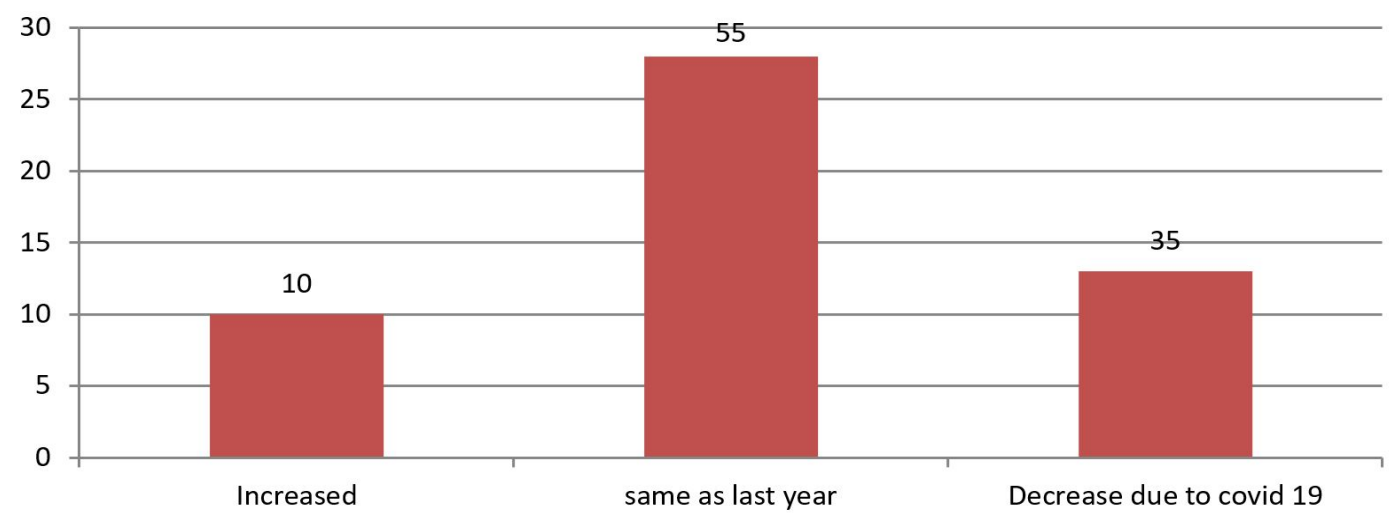

As shown in a report

Figure 4: Effect of COVID 19 on employment levels compared to previous year

\subsection{Effect of COVID 19 on profit level}

Figure 5 below shows that micro and small scale enterprise connected with both in manufacturing; urban agriculture, trade, services and construction areas demonstrated a critical decrease of benefits at 78\% because of COVID 19 outbreak. On normal 14\% of the enterprise detailed a similar benefit with the past year. There were some little detailed increments in seals at $8 \%$. The finding of this study is similar with the report of international organization for migration 2020 that states small and medium scale enterprise faced $65 \%$ decrease in revenue or seal on average. On the same trend the finding of the paper supports the result of Dodd (2020) which states that the company seals revenue had declined by $17.81 \%$ on his study on the impact of Covid 19 on seals and profit in US business.

Figure 6 below reviews COVID 19 out brake caused a critical down in seals. 72\% micro and small scale enterprise encountered a decrease in seals level. The other $10 \%$ and $18 \%$ were experienced expanded and same as a year ago individually 


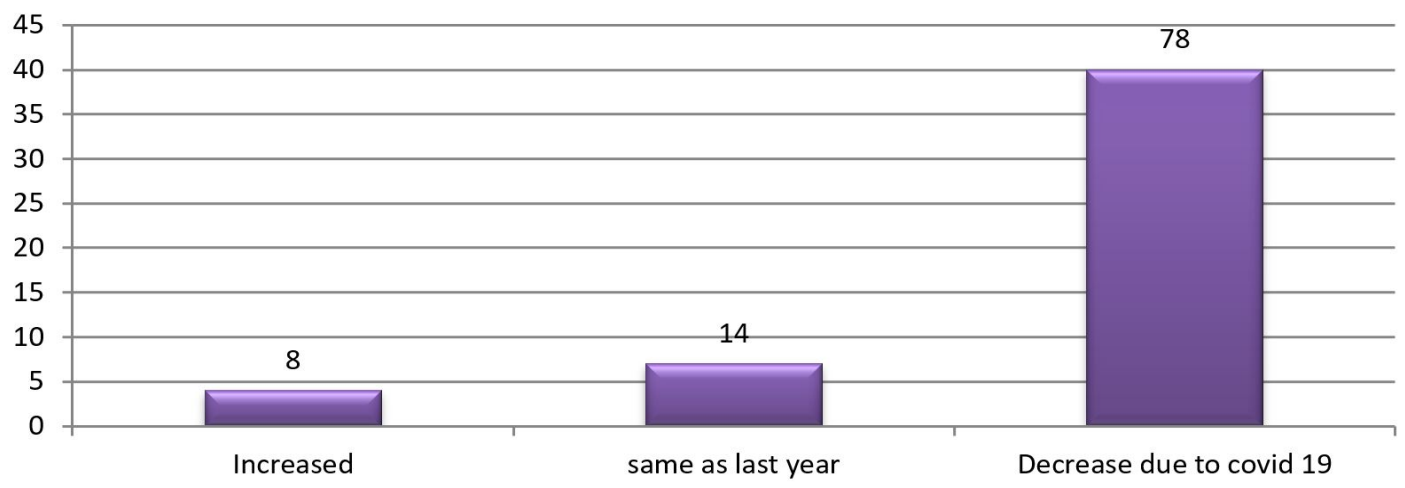

Figure 5: change in profit level

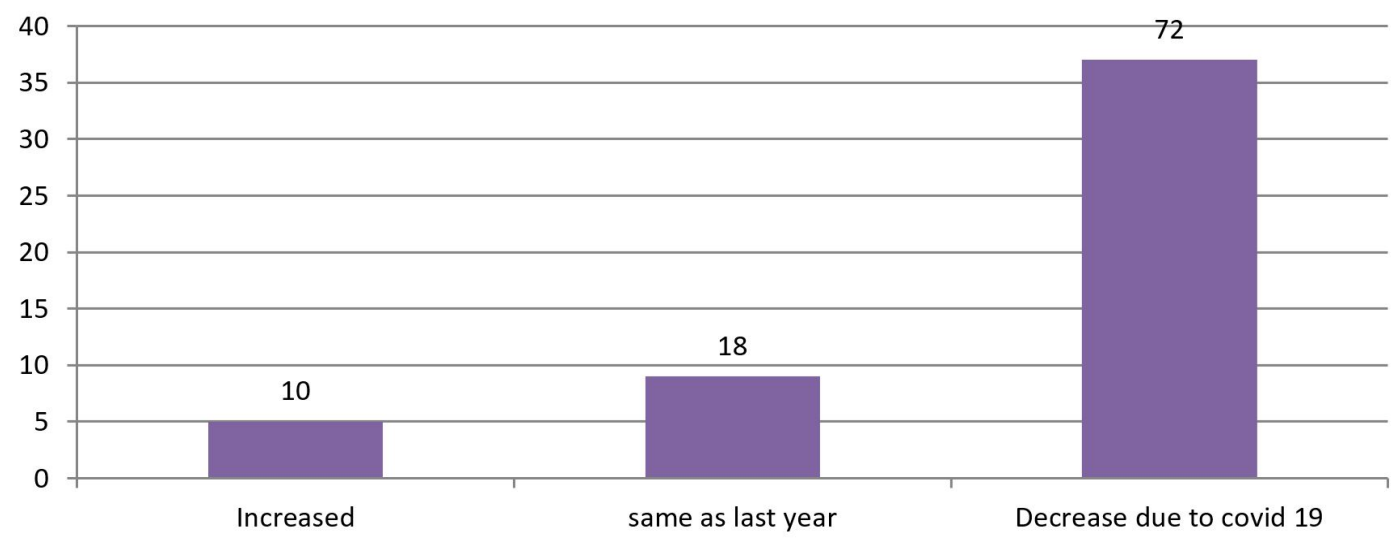

Figure 6: Change in seals level

\subsection{Effect of COVID 19 on micro and small scale enterprise operational costs}

Figure 7 below shows that COVID 19 flare-up influenced operational expenses. Because of the out brake $49 \%$ of the micro and small scale enterprise caused transportation costs, $10 \%$ expansion pay for their representatives, 10\% lease for distribution center and 31\% for different exercises individually contrasted with the ordinary condition. The aim of this study back up the conclusions of Zou et al. (2020), who found that more than half of the firms experienced a significant increase in operating costs as a result of order cancellation, late delivery, and production deflation. Some of them had to deal with default and contract infringement compensation. Staff salaries, insurances, rent payments, accounts payable settlement, and loan repayment all put pressure on companies.

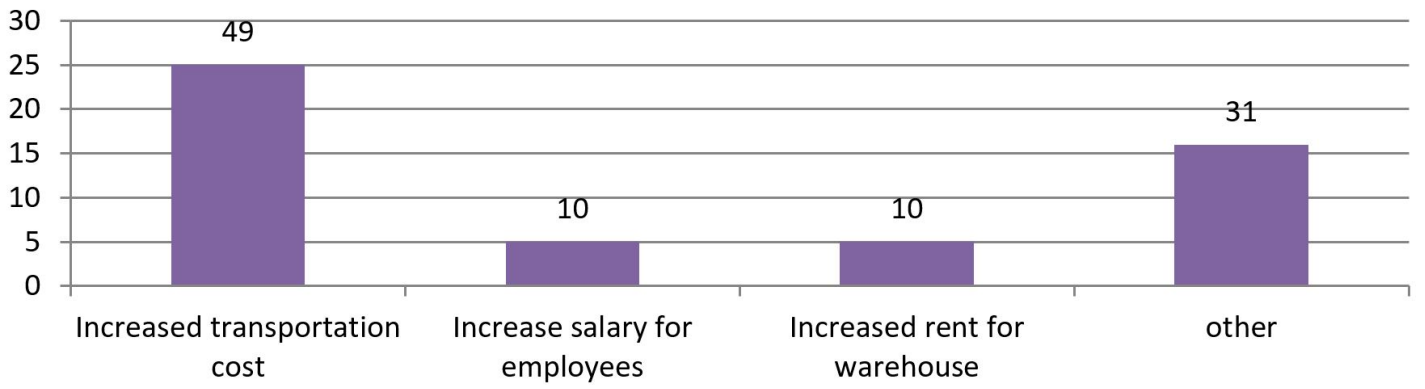

Figure 7: Operational cost of small scale enterprise

\subsection{The effect of COVID 19 on cost of raw materials}

Figure 8 below showed that 59\% of micro and small scale enterprises announced the most elevated impact on raw materials during COVID 19 with lack of raw materials and 
products bought because of isolate measures. $29 \%$ of tiny, small, and small firms detailed the fact that cost for raw materials are expanded because of the flare-up and $12 \%$ expense of micro and mall scale enterprises caused for other crude material.

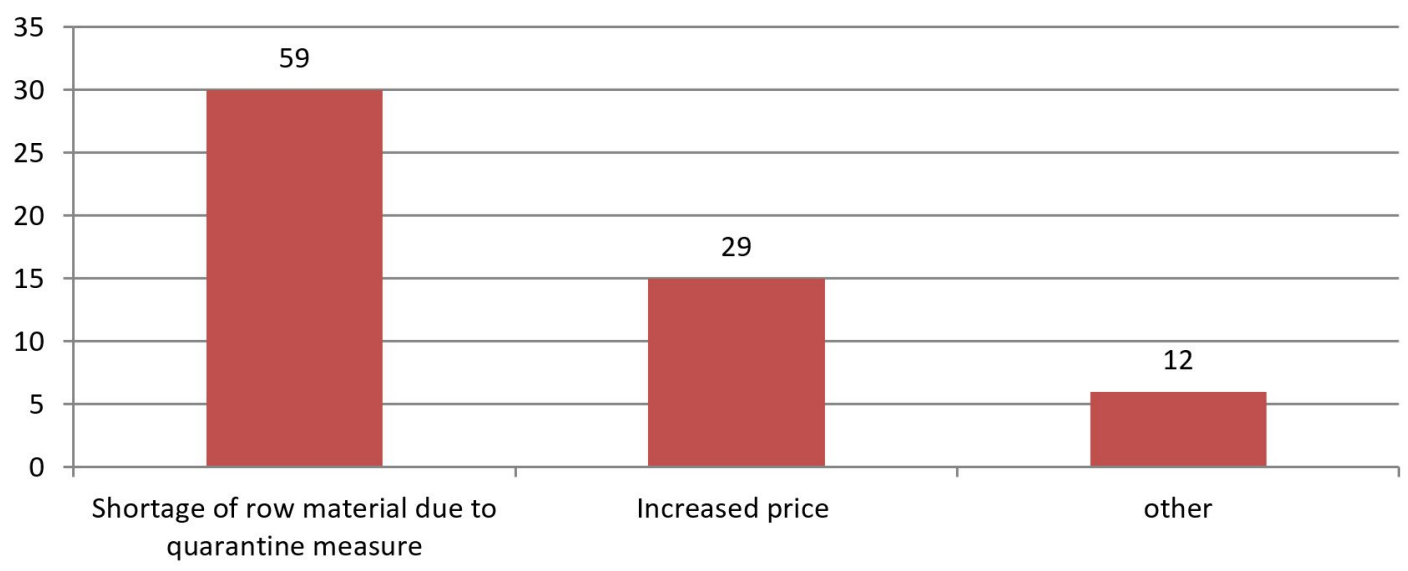

Figure 8: Cost of raw materials for micro and small scale enterprise

\subsection{The effect of COVID 19 on supply chain}

To accommodate the sources of change and uncertainty, supply chains need teamwork. Gomez-Padilla and Mishina (2011). Companies have placed a strong emphasis on supply chain management in order to adapt to changes in the environment, increase operational efficiency, and achieve a competitive edge. Sajad and his colleagues (2019). Furthermore, companies that are part of the same network need active supply chain integration in order to boost their overall efficiency and gain the most benefits as a group. As a result, Supply Chain Management (SCM) has begun to be seen as a critical foundation to develop business skills. Consequently, several enterprises have started to recognize that SCM will help them create a long-term competitive edge for their commodities in a highly competitive market jingjing (2011). The virus impacted supply chain ties, such as the producing and distribution of raw materials, logistics, and so on, as seen in Figure 9 below 48 percent (supply of raw materials and other production and operation materials). Similarly, there is complete interruption, adequate availability, and 12 percent and 23 percent respectively due to the outback. A standard supply of raw materials, on the other hand, is available at a 17 percent discount. Zou et al. (2020), Gong et al. (2011), Gomez-Padilla and Mishina (2011), Vafaei et al. (2019) found similar results in their report on the effect of the COVID-19 pandemic on firms: a survey in Guangdong Province, China.

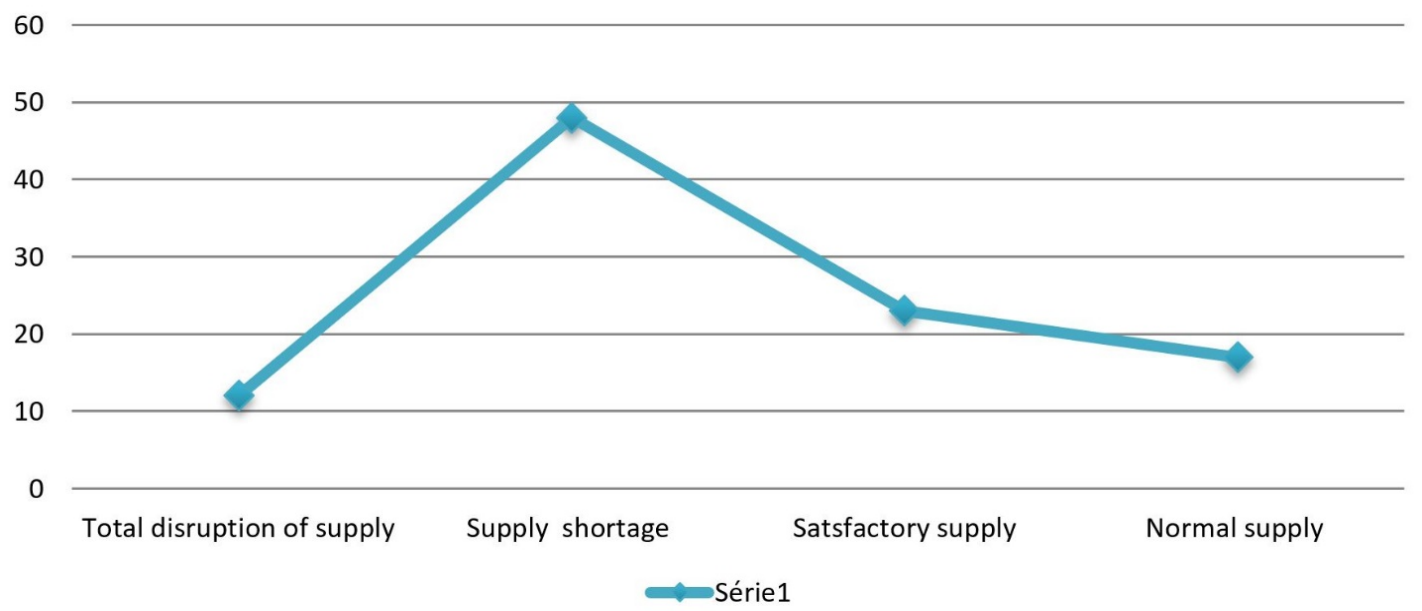

Figure 9: Supply chain for micro and small scale enterprise 


\subsection{Challenges for the enterprise post COVID 19}

Respondents were posed a progression of inquiries to survey the difficulties that tiny and tiny firm would look within that long in addition transient time frame following COVID 19 emerges. Figure 10 below shows that respondent's estimates south west Ethiopia financial execution over the accompanying 4 to a half year. $47 \%$ of the respondents where all the more decidedly anticipated that the economy should improve, $23 \%$ of the respondent felt that the economy would be the equivalent to the earlier year and the staying $14 \%$ of the respondent were skeptical and uncertain anticipating that the degree of tasks should diminish post COVID 19.

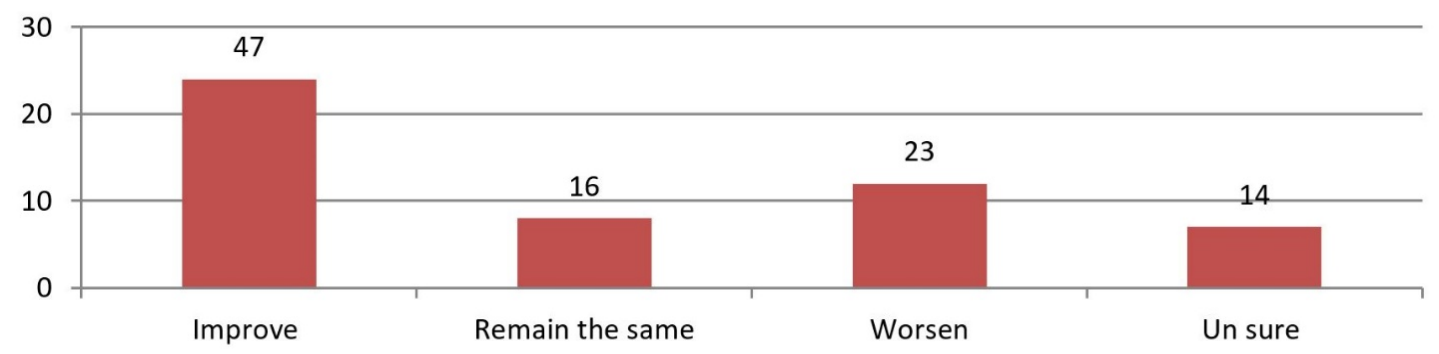

Figure 10: Respondents forecasts economic performance in the 4-6 months post COVID 19

\subsection{Micro and small scale enterprise expected change of employment levels in the 4-6 months post COVID 19}

Figure 11 below shows that greater part of micro and small scale enterprise served (53\%) demonstrated that business levels would equivalent to a year ago in the 4 to a half year. $39 \%$ of micro and small scale enterprise extended expanded work throughout the following 4 to a half year because of COVID 19, the other $8 \%$ extended a diminished in work more than 4 to a half year because of the flare-up.

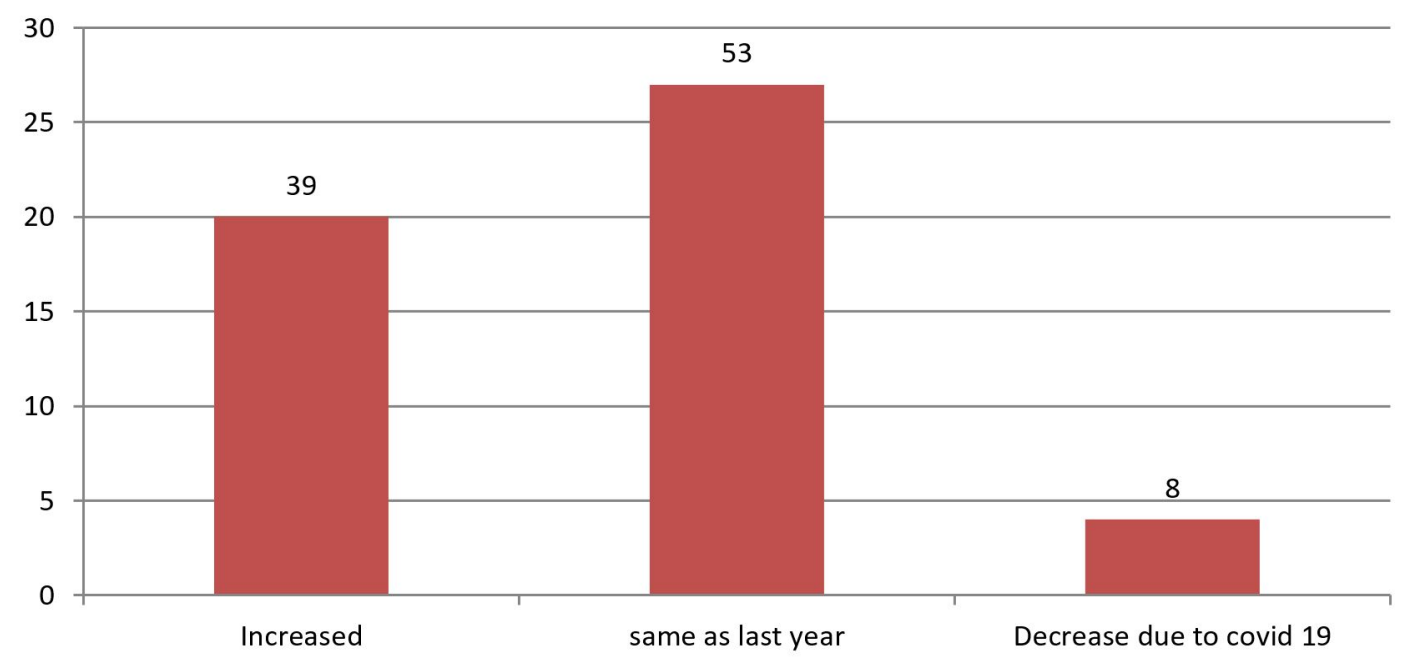

Figure 11: Expected change in employment level over 4-6 months

\subsection{Effect of COVID 19 on micro and small scale enterprise access to finance}

Figure 12 below shows that greater part of the respondents below in Figure 11 In terms of internal funding sources, local and small size enterprise recorded a substantial net decline in expected availability of funds ( 55 percent), which reflects projected tailwinds for economic activity and has significant implications for the firm's value and while 29 percent of local and smaller firms have had little effect, 16 percent of firms have been unaffected by the outbreak. Calanog (2020) empirical analysis of the impact of Covid 19 on business access to finance backs up the results of this paper. 


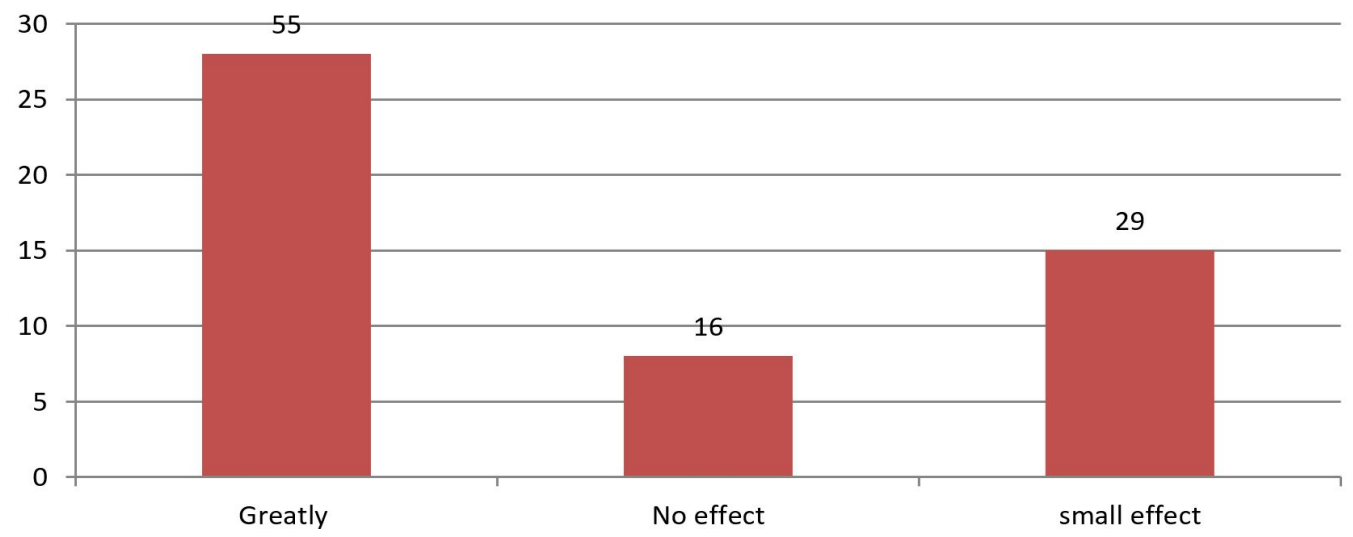

Figure 12: Micro small scale enterprise accesses to finance

\subsection{Effect of COVID 19 on government tax revenue collected from micro and small scale enterprise}

Table 2 and Figure 13 below shows that there is no change in tax revenue collected from manufacturing sector before and after COVID 19 whereas the tax collected from urban agriculture reduced from $57 \%$ to $47 \%$ on the other hand tax collected from trade sector increased from $49 \%$ to $59 \%$, tax collected from service sector decreased from $42 \%$ to $33 \%$ and the tax collected from construction sector reduced from $39 \%$ to $31 \%$ due to corona virus outbreak. The findings of this paper are backed up by Reuters (2020), which claims that Japan's tax revenue is down 9.2 percent, and the study's findings back up the empirical result of 8.5 trillion dollars compared to an approximate 11 percent decline in 2019 in Eun Joo (2020).

Table 2: Effect of pandemics on government tax revenue collected from Micro and small scale enterprise

\begin{tabular}{llll} 
Sectors & $\begin{array}{l}\text { Share of tax revenue } \\
\text { Manufacturing }\end{array}$ & $\begin{array}{l}\text { Share of tax revenue } \\
\mathbf{2 0 1 1} \text { / before COVID 19 }\end{array}$ & $\begin{array}{l}\text { Tax revenue } \\
\text { change /effect/ }\end{array}$ \\
Urban agriculture & $21 \%$ & $21 \%$ & $0 \%$ \\
Trade & $57 \%$ & $47 \%$ & $-10 \%$ \\
Services & $49 \%$ & $59 \%$ & $10 \%$ \\
Construction & $42 \%$ & $33 \%$ & $-9 \%$ \\
\hline
\end{tabular}

Sources: zonal tax and revenue authority

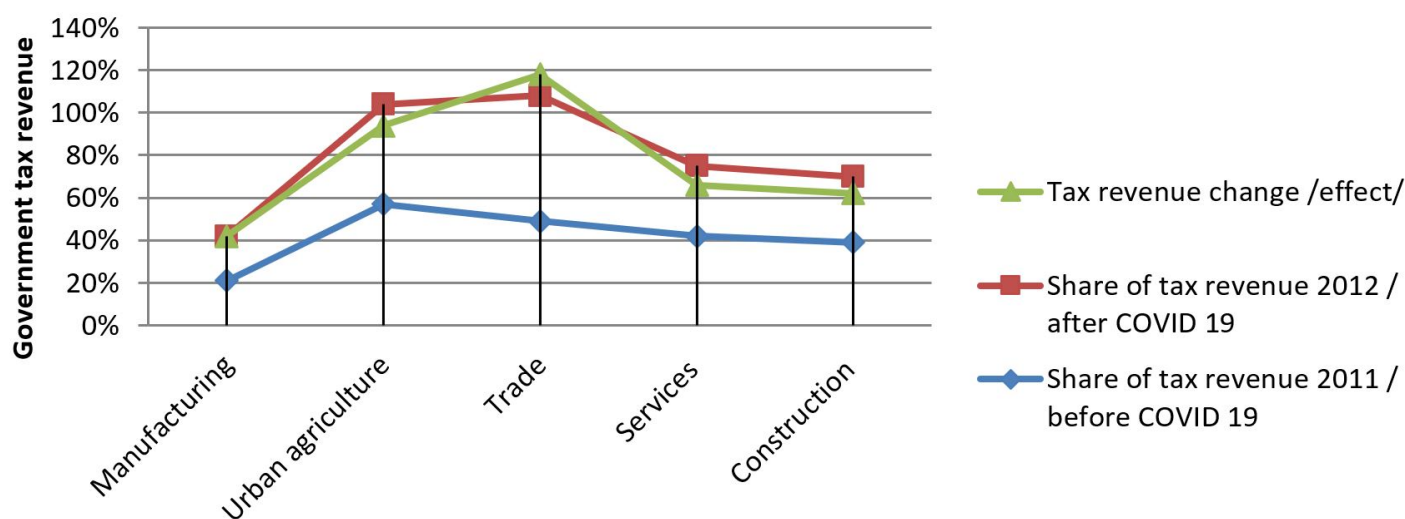

\section{Enterprise type}

Figure 13: government tax revenue collected from micro and small scale enterprise 


\section{CONCLUSION AND POLICY IMPLICATION}

\subsection{Conclusion}

The flare-up of the novel COVID 19 The global epidemic has resulted in a significant interruption in terms of politics, monetary, social in relation to strict and money related exercises of the total populace. In the same way as other creating areas, in Ethiopia, the pandemic prompted an enormous harm on financial exercises as a rule micro and small scale enterprise specifically following limitation on living creatures' portability by methods of administration and working at home exhortation. This is a prime illustration assessment investigates the COVID 19 has an impact for micro and tiny firm activity in south west Ethiopia and the examination found that creation level of micro and small scale enterprise in south west Ethiopia hung essentially during the COVID 19 outbreak at a rate of 59\%, COVID19 likewise affected the work level at a rate of 35\% diminishing, $78 \%$ micro and small scale enterprise studied revealed a lessening in benefit level because of the pandemic, $72 \%$ abatement in seals level, 49\% expansion in operational cost, 59\% lack of crude material, 57\% reduction in charge income gathered and $55 \%$ micro and small scale enterprise admittance to fund enormously influenced because of the flare-up.

\subsection{Policy Implications}

So as to guarantee the presence of micro and small scale enterprises as going concern in south west Ethiopia, the accompanying arrangement suggestion is given.

- A part of micro and small scale enterprises are right now attempting to recoup in the wake of the COVID19 emergency. Improved admittance to fund, with diminished loan fee credits, is a basic advance that would assist business with managing the prompt outcome of the emergency and the nearby Government has an imperative task to carry out through strategy to improve admittance to back and the accessibility of business capital especially for micro and small scale enterprises.

> Micro and small scale endeavors are defied with high business costs, especially for transportation, rents, stockrooms, and compensation. This is a test that has a high penchant to hurt business gainfulness and supportability in the region. Direct awards to decrease such expenses ought to be thought of.

$>$ Micro and small scale ventures need to incorporate danger the executives procedures into the core of their key arranging measure, in status for usage in future catastrophe situations.

> The nearby government should scan diverse market outlets for the results of micro and little scope ventures and encourage linkage with different other businesses

> The neighborhood governments additionally look through different wellsprings of salary to pick up the assessment income lost from micro and small scale venture because of the pandemic and the nearby government ought to create distinctive system of making the casual business area in to formal business area.

> Micro and small scale endeavors need to move their activity framework in accordance with countries requirement for battling against COVID-19. The venture need to redirect their assets towards delivering items that could assist people in general with limiting the transmission of the pandemic, for example, creating neighborhood cleansers for hand wash and veils.

> Micro and small scale organizations ought to improve their current plan of action of tending to their client needs by acquainting electronically upheld entryway with entryway conveyance administration. They may move their activities to COVID-19 started items if their ability permits them to do as such. They likewise return to their current evaluating techniques to empower the purchasing choice of the baffled clients.

- Micro and small scale venture evenly occupied with similar activity classes it is necessary for business to function. Agreeably in addition strongly with defeat it is effect COVID-19 
and in workplace. In spite of the fact that they can seek a solitary normal client, they can share assets for their creation to lessen their creation costs through their participation.

> Academic organizations, for example, colleges, preparing focuses, universities on the field, research establishments, and others ought to give information base counsel and backing for the area on the best way to be fruitful during and after the corona infection.

\subsection{Limitations and directions for further studies}

The examination have the accompanying constraints first, the consequences of this investigation are not summed up to different segments other than Micro and small scale enterprise. Second the investigation utilized qualitative data that can't fill the advantage of quantitative data. Thus, there must be further examination on the effect of COVID 19 in various benefit arranged and non- benefit arranged associations and even in the micro and small scale enterprise by joining other comports of operation that have not been contacted in the investigation.

\section{REFERENCES}

Calanog, V. (2020), ECB Examines impact of Covid 19 on access to finance of enterprises, Moody's Analytics, USA.

deRitis, C., Calanog, V. and Pieretti, C. (2020), COVID-19: Potential Effects on the US Economy, CRE Sectors, and CRE Finance Markets, Moody's Analytics, USA.

Dodd, D. (2020), The impact of Covid 19 on sales and profits of us business, Customer Think, Coronado, CA.

Duffin, D.J. (2020), "Analysis of COVID-19 mathematical and software models: or How NOT to set up a Software Project", Wilmott, Vol. 2020, No. 110, pp. 66-71. https://doi.org/10.1002/wilm.10890.

Economic Commission for Africa (2020), Economic Impact of the COVID- 19 Report on Africa, Addis Ababa, Ethiopia

Ethiopia. Ministry of Health (2020), "Ministry of Health COVID update report", available at: http://www.moh.gov.et/ejcc/ (accessed 06 May 2020).

Eun Joo, H. (2020), "Tax policy and administration response to Covid 19", in Organisation for Economic Co-operation and Development (Org.), Revenue and Statistics in Asia and Pacific Economies, OECD Publishing, Paris.

Gomez-Padilla, A. and Mishina, T. (2011), "Comparison of the performance of a supply chain under rebate and option contracts", Brazilian Journal of Operations \& Production Management, Vol. 8, No. 2, pp. 51 65. http://dx.doi.org/10.4322/bjopm.2012.003.

Gong, J., Ogasawara, T. and Suzuki, S. (2011), "Supply chain operational performance and its influential factors: cross national comparison between Japan and China", Brazilian Journal of Operations \& Production Management, Vol. 8, No. 2, pp. 67-87. http://dx.doi.org/10.4322/bjopm.2012.004.

Goshu, D., Ferede, T., Diriba, G., and Ketema, M. (2020), Economic and Welfare Effects of COVID-19 and Responses in Ethiopian. Economic Policy Research Institute (EEPRI), Delhi.

Hoepfl, M.C. (1997), "Choosing Qualitative Research: A primer for technology education Researchers", Journal of Technology Education, Vol. 9, No. 1. Available at: http://scholar.lib.vt.edu/ejournals/JTE/v9n1/hoepfl.html (accessed 08 April 2020).

International Labour Office (2015), Small and medium-sized enterprises and decent and productive employment creation, International Labour Office, Geneva.

Jingjing, G.T.O.S.S. (2011), "Supply chain operational performance and its influential factors: Cross national comparison between Japan and China", Brazilian Journal of Operations \& Production Management, Vol. 8, No. 2, pp. 67-87.

Kothari, C.R. (2004), Research methodology: methods and techniques, 2nd ed., India, New Delhi, New Age International Limited.

Kumar, A., Luthra, S., Mangla, S.K. and Kazançoğlu, Y. (2020), “COVID-19 impact on sustainable production and operations management", Sustainable Operations and Computers, Vol. 1, pp. 1-7, available at: https://papers.ssrn.com/sol3/papers.cfm?abstract_id=3562570 (accessed 08 April 2020). 
Ozili, P and Arun, T. (2020), Spillover of COVID-19: Impact on the Global Economy, University Library of Munich, Germany.

Planning and Development Commission, (2018). Poverty and Economic Growth in Ethiopia, 995/962015/16, Addis Ababa.

Reuters, (2020), "Tax policy and administration response to Covid 19" in Organisation for Economic Cooperation and Development (Org.), Revenue and statistics in Asia and pacific economies, OECD Publishing, Paris.

Triggs, A. and Kharas, H. (2020), The triple economic shock of COVID-19 and priorities for an emergency G-20 leaders meeting, Washington, DC, Brookings.

Vafaei, S., Bazrkar, A. and Hajimohammadi, M. (2019), "The investigation of the relationship between sustainable supply chain Management and sustainable competitive advantage according to the Mediating role of innovation and sustainable process management", Brazilian Journal of Operations \& Production Management, Vol. 16, No. 4, pp. 572-80. http://dx.doi.org/10.14488/BJOPM.2019.v16.n4.a3.

Wilkinson, N. (2020), Impact of Covid 19, firms, jobs and women's employment. International Growth Centre, United Kingdom.

World Bank (2020), available at: https://www.worldbank.org/en/who-we-are/news/coronavirus-covid19 (accessed 18 February 2021).

Zou, P., Di, H. and Meng, L. (2020), "The impact of the COVID-19 pandemic on firms: A survey in Guangdong Province, China Global Health", Research Policy, Vol. 5, No. 1.

Author contributions: All the authors contributed equally to this paper. 